\title{
Ouverture de 'Global Tourism in Global Markets'*
}

\author{
Nicola Bellini ${ }^{* *}$, Silvio M. Brondoni ${ }^{* * *}$
}

\begin{abstract}
For a long time, tourism has been to many scholars of management a less than optimal choice in their academic and research strategies. Some of them would have probably even denied to tourism the status of "industry". Even economists, including scholars of development, looked at tourism with skepticism. Low-tech, seasonal, knowledge-unintensive tourism was the worst of the possible postindustrial outcomes and no serious economic policy could be based on it. This scenario has changed very rapidly in recent years. Both internationally and in Italy, the number of scholars, institutes, journals, publications and teaching programs dealing with tourism has increased, involving several disciplines. Globalisation has also established new horizons in terms of tourism variety and development, encouraging the emergence of new tourist profiles. The traditional mass tourism model. has greatly changed, generating tourism supply and demand systems characterized by flexible production, organization and consumption models (dominated by the internet, the sharing economy, low-cost travel, B\&Bs, etc.).
\end{abstract}

Keywords: Global Tourism; Global Markets; Global Tourism Management; Tourism Flows; Mass Tourism; Experience Tourism; Sensations Tourism; Agrofood District

\section{Overture}

It is the first time that Symphonya. Emerging Issues in Management devotes an issue to tourism (and a second one will follow) and we believe that this requires some explanation. For a long time, tourism has been to many scholars of management a less than optimal choice in their academic and research strategies. Some of them would have probably even denied to tourism the status of "industry" and a large majority would have shared the opinion that, in any case, it was not an interesting one, especially in countries like Italy, where a crowd of small and medium sized firms were simply exploiting the extraordinary heritage of nature and

\footnotetext{
* The Authors: N. Bellini § 2, S.M. Brondoni § 1

** Full Professor of Management, La Rochelle Business School (bellinin@esc-larochelle.fr)

*** Editor-in-Chief Symphonya. Emerging Issues in Management (silvio.brondoni@ unimib.it)
}

Edited by: ISTEI - University of Milan-Bicocca

ISSN: 1593-0319

Bellini, N., \& Brondoni S. M. (2016). Ouverture de Global Tourism in Global Markets, Symphonya. Emerging Issues in Management (symphonya.unimib.it), 1, 1-6. 
history with a rentier approach. Only some large corporations, mostly abroad, seemed to realize a variation of the "industrialization of services", by importing management tools and methods that had been brought to maturity in the hardcore industries.

Even economists, including scholars of development, looked at tourism with skepticism. In the predominant industrialist view, only manufacture would guarantee that a country or region was on the "high road" of development. Lowtech, seasonal, knowledge-unintensive tourism was the worst of the possible postindustrial outcomes and no serious economic policy could be based on it.

In many academic communities, tourism research was left almost completely in the hands of geographers, who based their understanding of the tourist phenomenon on their peculiar (and often creatively interdisciplinary) descriptive techniques of places and of their demographic, social, economic and physical evolution.

This scenario has changed very rapidly in recent years. Both internationally and in Italy, the number of scholars, institutes, journals, publications and teaching programs dealing with tourism has increased, involving several disciplines (some of the most remarkable contributions coming, e.g., from sociology) and fully adopting both the best standards (as well as some of the worst habits) of contemporary social sciences.

There are manifold reasons behind this change. First of all, figures themselves impose to take tourism seriously. According to the United Nations World Tourism Organization (UNWTO), tourism amounts to $10 \%$ of the global GDP and $7 \%$ of the world exports, originating one out of eleven jobs. This is the result of a spectacular growth of the phenomenon: there were 25 million international tourists in 1950 and almost 1.2 billion in 2015, adding to more than 5 billion domestic tourists (UNWTO, 2016). Because of this, tourism has undoubtedly been a major factor of resilience for both local and national economies during the recent world economic crisis and an engine of export-led growth.

On this background, the dynamics of tourism presents a number of features of the greatest interest to both practice and research:

- growth coincides with a reshuffling of the global market that is marked by the role of emerging economies, led by China, which is now the largest source of outbound flows. According to UNWTO (2016), "the market share of emerging economies increased from $30 \%$ in 1980 to $45 \%$ in 2015, and is expected to reach $57 \%$ by 2030 , equivalent to over 1 billion international tourist arrivals". In the medium and long term this dramatizes several problems ranging from adequate transport infrastructures to intercultural management;

- sustainability has been highlighted in several occasions as a major challenge for contemporary tourism: it is both a collective challenge for public policies in charge of preserving natural and historic heritage and a management challenge for individual destinations and companies. It is not only a vital challenge for an industry that depends on the quality of the "experiencescape", but also a complex one, because it involves social and economic dimensions, as it is shown by the rising anti-tourism movements worldwide;

- the impact of Internet is unparalleled, compared to other industries. Increasingly through mobile applications, Internet hosts a large part of the customer's decision 
making and buying process and, through social networks and specialized sites, shapes the reputation of companies and destinations;

- new companies have emerged and grown, taking full advantage of the web. They have redesigned the industry, by introducing advanced forms of intermediation, based on platforms that are managed globally, but with the ability to serve individual companies in the most peripheral areas. In some cases, these platforms have also been able to intercept the societal mood favoring alternative types of economic relations (i.e. the so-called sharing economy);

- as a reaction to the market power of these global platforms, large companies have designed and are implementing strategies based on mergers and acquisition and on their ability to dis-intermediate the relationship with the customer on a global scale. At the same time also individual companies try to escape the dominance of global platforms though a much more sophisticated (although relatively low cost) approach to the Internet and to social networks;

- the interaction with other industries has always been a significant feature of tourism, but the ability of cross-industry networking has proved increasingly decisive for the competitiveness of both tourism and the contributing industry. Tourism relates to these industries in many respects: to strengthen the identity of destinations and tourist packages, to improve quality, to re-design and reauthenticate experiences etc. There are many examples of industries (from the agrifood to the fashion and luxury), that are increasingly integrating tourism in their approach to the market, not just in promotional terms, but also as new dynamic market spaces;

- technological innovation has become a key factor of competitiveness, but it is not limited to the mere application of technologies developed in other industries (and especially of ICTs). Either directly or indirectly, tourism is the experimental field of a number of new technologies that contribute to its efficiency, but also to re-invent tourist products and experiences (e.g. through innovative logistics and transportation, virtual environments, humanoid robotics etc.) or to safeguard tourist assets (e.g. through biotechnologies, green technologies etc.). In other cases, tourism is concerned by the diffusion of innovation through "related variety" mechanism (e.g. health tourism);

- human capital in tourism is also changing its role and characters. Let us just consider the amount of knowledge required in order to manage highly internationalized, but also highly fragmented tourist flows, even at relatively low operational levels. In the past, the industrialist critique has an easy task of dismissing tourism as the employer of low-skilled, temporary and underpaid workers. This picture is increasingly unrealistic and contemporary tourism challenges educational systems that reflect an outdated vision of the labor content of these businesses (like the Italian one).

Facing all these changes, scholars of management are required to devote to tourism a much more consistent and qualified attention than in the past. The good news for researchers is that this effort cannot be realized only by recycling concepts and tools into "just another new sector", but creative efforts are needed to develop tourism-specific analysis, based on paradigms that derive from a more realistic view of market dynamics (like the "market-driven management" approach that 
characterizes much of the research work presented in this journal) and of value creation (like the "service-dominant logic" in marketing).

In other words, tourism is rapidly moving from a theory-importing research field to a theory-exporting one. Also because of the paradigmatic significance of "postmodern" consumption in tourism, this field of research is now providing the ground to develop concepts and tools that are bound to have much wider applications. The solutions given to issues like the experiential dimension of consumption, the shaping of e-reputation, the role of information systems in interpreting market dynamics, the co-creation by customers (just to name a few) are likely to be relevant on much more than just tourism.

\section{Global Tourism Management and Agro-Food Districts}

Over the past 50 years, global tourism has undergone tremendous growth, with 2015 registering over one billion international arrivals versus around 25 million in 1950.

Globalisation has also established new horizons in terms of tourism variety and development, encouraging the emergence of new tourist profiles, where the motivations and traditional behaviours are replaced by more volatile and contradictory behaviours.

The traditional mass tourism model that emerged in the "60s characterized by standardized tourism products and markets dominated by the supply (especially airlines and tour operators) has greatly changed, generating tourism supply and demand systems characterized by flexible production, organization and consumption models (dominated by the internet, the sharing economy, low-cost travel, B\&Bs, etc.). These new trends have generally fostered the emergence of individualistic preferences of tourists and travellers with different backgrounds, ages and incomes but united by the search for 'wellbeing tourism', first of all food, which dominates and far surpasses all other motivations of tourism and travel in Italy (cultural, monumental, study, religious, etc.)

In the Mediterranean, and particularly in Italy, these profound changes extol the drivers of excellent quality of tourism production and consumption. Affirming in this new context (for the first time globally, after EXPO 2015) is the priority of 'High-Quality Italian Lifestyle' food consumption, exalted by quality food districts as a 'premium image' of economically sustainable tourism on a local level and socially sustainable on a global level.

Quality tourist-agro-food districts are production areas with a significant economic presence and production interrelationships and interdependencies between tourism, agro-food and agricultural enterprises, qualified by typical or traditional production. 
Figure 1: Italy - Regional Map of Quality Agro-Food Districts

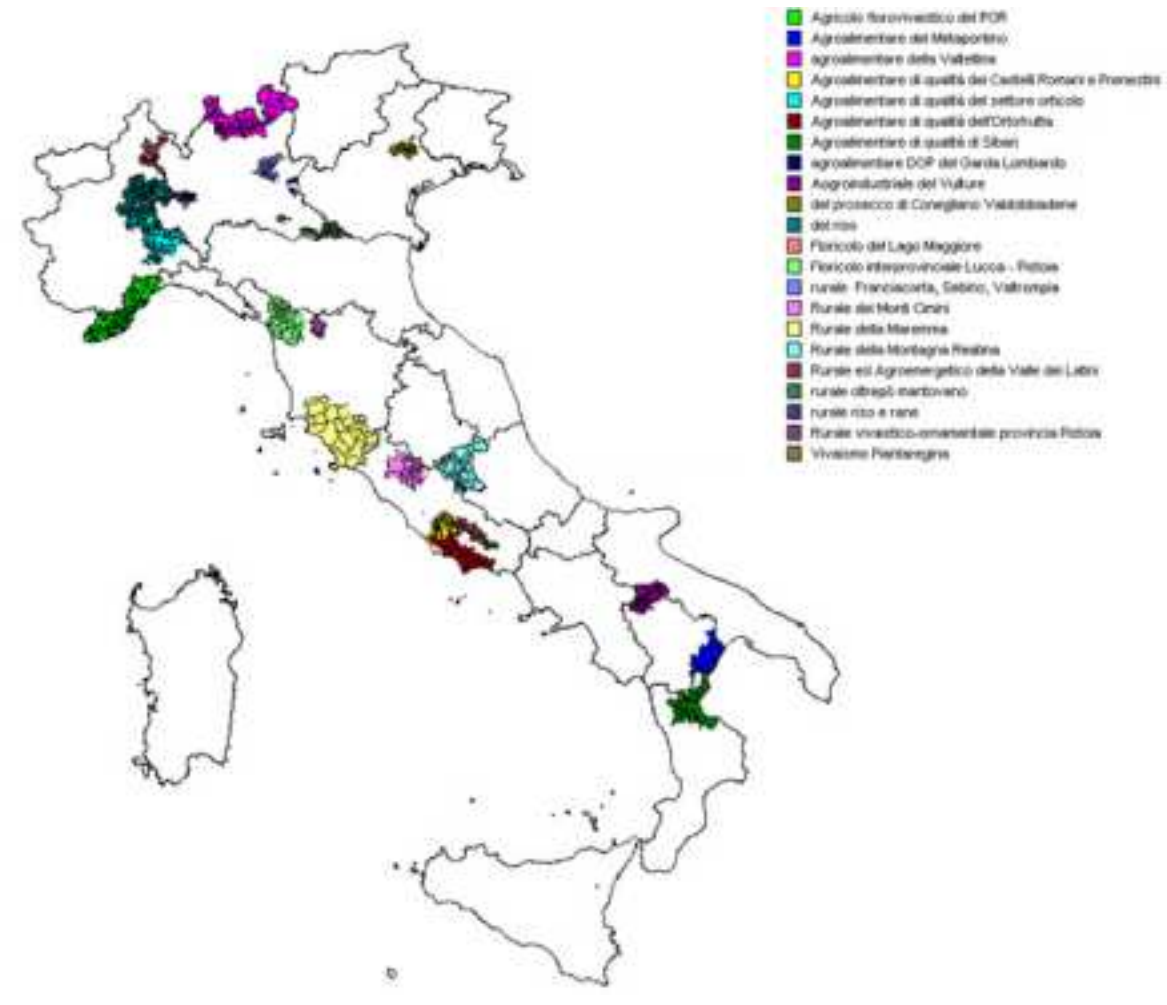

High quality food districts develop from the strong regional entrenchment of the production activity of reference. Just some of the best known include: Venetian wine specialization, Lombardy agricultural livestock, the ham districts of Parma and San Daniele, the cheeses of Parmigiano Reggiano, Grana Padano and Pecorino Romano, Padano tomatoes, Gragnano pasta, the Vulture beverage industry (wine and mineral waters), the fruit and vegetable production in Metapontino, in the plains of Sybaris, in the Alessandria region and in the Lombard Po Valley, the rice culture of Piedmont and Lombardy, and so forth

However, in the Italian tourism development policies, high-quality agro-food districts clash with global tourism management due to their different economic and financial conceptions of the time factor.

Global tourism management is in fact conditioned by the strict rules of financial profitability indicators at the base of 'time-based competition' of global tourism products.

By contrast, agro-food districts base their identity on local culture and traditions and thus their development disregards the 'time-based' approach, preferring to connote themselves as a physical reality, with a static location, where different operators interact with social relationships, relations of proximity and with rules designed to foster the convergence of interests and problem sharing.

The different economic and financial power relations that characterize districts and global corporations therefore bring into focus the 'risk of transformation and dispossession' of quality agro-food districts (and once dispossessed, their abandonment) by global tourism operators. 
Will public policies be able to intervene with effective planning and intervention mechanisms to successfully defend the local actors and the territories? Will the multiple institutions (national, regional and local) that 'live' on tourism (today the largest Italian industry) be able to develop robust enhancement and support policies for the sophisticated system of relations to be put in place between quality agrofood districts and global tourism operators?

\section{Bibliography}

Bellini, N. (2015). Smart Specialisation in Europe: Looking Beyond Regional Borders, Symphonya. Emerging Issues in Management (symphonya.unimib.it), 1, 22- 29.

http://dx.doi.org/10.4468/2015.1.03bellini

Bellini, N. (2004). Territorial Governance and Area Image, Symphonya. Emerging Issues in Management (symphonya.unimib.it), 1, 14-26.

http://dx.doi.org/10.4468/2004.1.03bellini

Bisio, L. (2005). Global Companies and Global Regulation, Symphonya. Emerging Issues in Management (symphonya.unimib.it), 1, 87-101

http://dx.doi.org/10.4468/2005.1.07bisio

Brondoni, S. M. (2015). Global Networks, Outside-In Capabilities and Smart Innovation, Symphonya. Emerging Issues in Management (symphonya.unimib.it), 1, 6-21.

http://dx.doi.org/10.4468/2015.1.02brondoni

Brondoni, S. M. (2014). Global Capitalism and Sustainable Growth. From Global Products to Network Globalisation, Symphonya. Emerging Issues in Management (symphonya.unimib.it), 1, $10-31$.

http://dx.doi.org/10.4468/2014.1.02brondoni

Brondoni, S. M. (2013). Innovation and Imitation for Global Competitive Strategies. The Corporation Development Models of US, Japan, Korea, and Taiwan, Symphonya. Emerging Issues in Management (symphonya.unimib.it), 1, 12 - 27.

http://dx.doi.org/10.4468/2013.1.02brondoni

Brondoni, S. M. (2005). Managerial Economics and Global Competition, Symphonya. Emerging Issues in Management (symphonya.unimib.it), 1, 14-38.

http://dx.doi.org/10.4468/2005.1.02brondoni

Brondoni, S. M. (2003). Ouverture de 'Marketing Research and Global Markets', Symphonya. Emerging Issues in Management (symphonya.unimib.it), 2, 1-16.

http://dx.doi.org/10.4468/2003.2.01ouverture

Brondoni, S. M. (2002). Global Markets and Market-Space Competition, Symphonya. Emerging Issues in Management (symphonya.unimib.it), 1, 28-42.

http://dx.doi.org/10.4468/2002.1.03brondoni

UNWTO (2016). Tourism Highlights. 2016 Edition. Madrid 